\title{
SOME REMARKS ON THE WOOD STRUCTURE OF PINZONA AND ALLIED GENERA OF THE SUBFAMILY TETRACEROIDEAE (DILLENIACEAE)
}

\author{
T. BARETTA-KUIPERS
}

Instituut voor Systematische Plantkunde, Utrecht.

\section{SUMMARY}

Included phloem of the concentric type is always present in the secondary wood of the genera Pinzona and Doliocarpus of the subfamily Tetraceroideae (Dilleniaceae). Raphide containing cells are found in the ray parenchyma of all genera of the Tetraceroideae, i.e. in Curatella, Davilla, Doliocarpus, Pinzona, and Tetracera. Arguments are put forward why the name mucilage cell for these raphide containing cells should be abandoned.

\section{INTRODUCTION}

Recently the Dilleniaceae received a great deal of interest from taxonomists as well as from anatomists. KUBITZKI $(1970,1971)$ revised the New World genera taxonomically. In his publication of 1971 he considered Pinzona a distinct genus, as HuTCHINSON had done before him (1964). Earlier it had been treated as congeneric with Doliocarpus and its only species was known as Doliocarpus coriaceus.

About the same time Dickison (1967) published his treatment of the morphology and anatomy of the Dilleniaceae; besides, the present author was engaged in a study of the wood anatomy of this family, with chief emphasis on material from South America. By that time the independent status of Pinzona was not yet generally accepted. Our material of Pinzona, consisting of 3 wellsized samples, had not yet been identified as such. At present it seems justified to publish a description of the wood of Pinzona, as it is always of interest to know whether the establishment of a genus, or, equally, the incorporation of a genus in another, is also supported by anatomical characters. There are also a few supplementary notes on some other genera of the Tetraceroideae treated by Dickison in his interesting and comprehensive paper.

\section{Results}

\subsection{Included phloem in Pinzona and Doliocarpus}

In its wood structure Pinzona, like Doliocarpus, differs in one aspect considerably from the other genera of the Tetraceroideae, i.e. the occurrence of included phloem. This feature is never present in Curatella nor in Davilla. In Tetracera, 
however, it may occasionally be present. Kubitzki noted included phloem in living material of Tetracera amazonica (personal communication). Dickison (1967) reported the occurrence of included phloem in Tetracera volubilis. MetCalfe \& ChalK (1950) record the occurrence of included phloem of the concentric type in Doliocarpus but without indication in which and in how many species. Dickison (1967) noted the occurrence of included phloem in

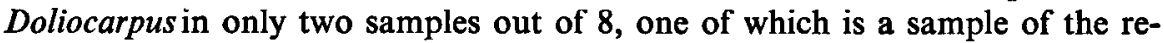
established genus Pinzona; the other sample was believed by him to belong to some other genus, as it had aberrant characters.

Of the wood samples of Doliocarpus and Pinzona present in the Utrecht wood collection all three samples of Pinzona (with a diameter of 5, 8, and $15 \mathrm{~cm}$, respectively) show included phloem of the concentric type. In all Doliocarpus species with samples having a diameter of 2 to $2 \frac{1}{2} \mathrm{~cm}$ or more this type of included phloem is present (a total of 26 samples). It is found in 7 species, i.e. Doliocarpus brevipedicellatus, D. dasyanthus, D. dentatus, D. macrocarpus, $D$. spraguei, D. paraensis, and an as yet unidentified species. No included phloem is found in our samples of $D$. paraensis and $D$. schottianus, which are less than $2 \frac{1}{2} \mathrm{~cm}$ wide. It seems therefore probable that all Doliocarpus species have included phloem, provided the diameter of the stem is more than 2 to $2 \frac{1}{2} \mathrm{~cm}$.

This is strikingly confirmed by KUBITZKI (1971): he said on page 5 that he found abnormal secondary growth in all Doliocarpus species seen by himself in the field. On page 13, however, he said that no Doliocarpus species has abnormal secondary growth. The reason for this contradiction is, as we learned from a personal communication in November 1971, that on the basis of herbarium material in which the wood is too small in diameter, he had never seen included phloem in Doliocarpus, but with living material its presence became evident. Correction of the error was unfortunately only partial.

Why Dickison did not mention included phloem for his material of Krukoff nr. 7020, later identified by Kubitzki as Doliocarpus dasyanthus, is not clear, as the wood sample of this same number in the Utrecht wood collection shows this included phloem strikingly.

\subsection{Structure-of the wood of Pinzona coriacea Mart.et Zucc.}

\section{Material investigated:}

Pinzona coriacea Uw 13880a, Surinam, Pulle 524, diam. $15 \mathrm{~cm}$

$P$. coriacea Uw 3490 , Surinam, Lindeman 5198 , diam. $5 \mathrm{~cm}$

P. coriacea Uw 17165, Brazil, Pires 51764, diam. $8 \mathrm{~cm}$

The bark is very thin, whitish and easily detached; in our samples merely present in patches. The wood is dark reddish brown, characterized in crosssection by the large solitary vessels, the broad rays, and the narrow concentric bands of included phloem, the bands being slightly darker than the wood.

Microscopic structure:

Vessels: solitary, scattered, on the average $2-3(-6)$ per square $\mathrm{mm}$, orbicular in cross-section, diameter from $100-500 \mu$. Perforations predominantly simple, horizontal, but in the smallest vessels sometimes oblique and scalariform with 


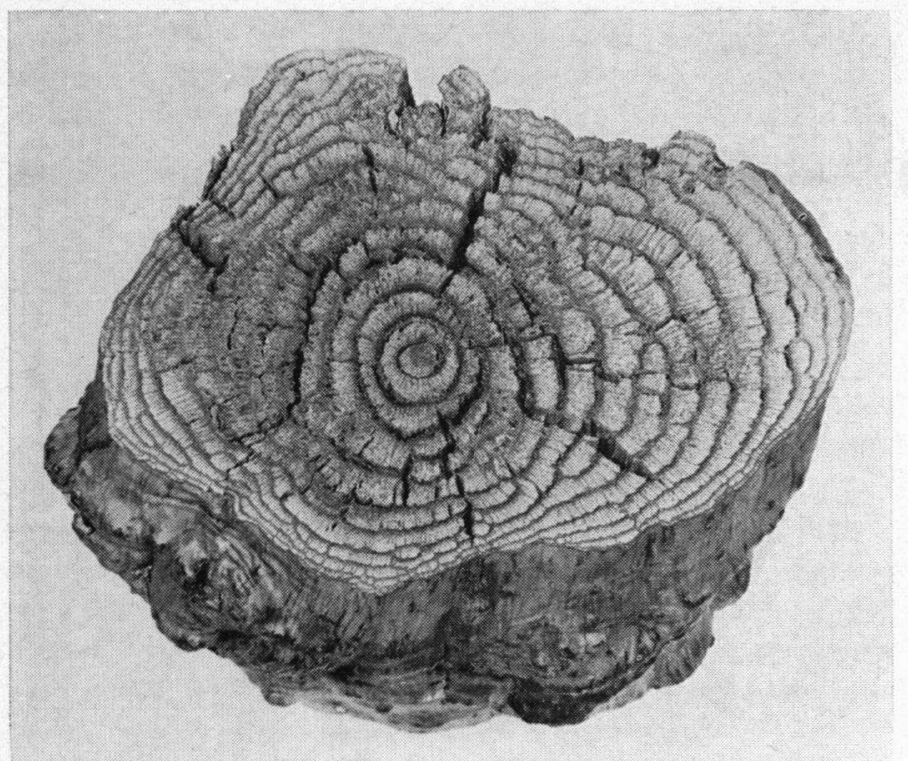

Pinzona coriacea Mart. et Zucc. Uw 13880a leg. Pulle nr. 524, Surinam

10-20 bars. Wall 4-5 $\mu$ thick; intervascular pits opposite, often elongated.

Fibre tissue: composed of fibre tracheids with numerous large, bordered pits with crossed apertures on radial and tangential walls; diameter about $30 \mu$, walls $4-5 \mu$ thick; $1000-2000 \mu$ long.

Rays: of two sizes. The uniseriate ones composed of upright cells, a few cells high. The multiseriate ones heterocellular, 8-20 cells wide, composed mostly of square and a few upright cells; as a rule $5-10 \mathrm{~mm}$ or more high. They contain quite a lot of raphides in cells slightly larger than the adjacent ray cells; the raphides fill the cell completely. Number of rays 4-9 per $\mathrm{mm}$, of which 0-1 wide rays.

Parenchyma: predominantly paratracheal, in a one-celled, incomplete vasicentric ring. Strands of $4-8$ cells.

Interxylar phloem: in concentric, more or less undulating bands from 350$700 \mu$ wide, containing groups of stone cells and a number of raphide containing cells.

The conclusion is that the wood structure of Pinzona is very similar to that of Doliocarpus and that it can easily be confused with it. The only difference found is a certain tendency towards a more complete parenchymatic sheath around the vessels and less diffuse parenchyma, than is the case in Doliocarpus and the other genera of the Tetraceroideae. 


\subsection{On raphide containing cells}

A problem in the Tetraceroideae is the occurrence of what Dickison(1967)called "secretory cells". He stated that raphides, where present, occur as a rule in large, mucilage containing ray cells. Moreover, he reported the presence of "secretory cells" without saying anything about the nature of the secretion and it is not clear if he referred to the above-mentioned raphide containing cells. The ray cells in which the raphides are found are on light microscopic level not distinguishable from other ray cells. Sometimes they are somewhat larger than the adjacent cells, but in that case the bundle of raphides has such dimensions that the cell is completely filled.

The meaning of the terms "secretory cell", "mucilage cell", "raphide cell", as used in the literature, does not seem uniform. Apparently for most older authors a mucilage cell and a raphide cell are identical, as they are always mentioned together (among others JANSSONIUS 1906); for many modern authors, however, this is not the case (FosTER 1949).

Therèse PoBÉguin (1943) made a very extensive study of Ca-oxalate crystals in Angiosperms. She stated that in a large number of plants the raphide cells contain mucilage, either in an earlier or in a later stage, and that for that reason for most authors raphide cells are synonymous with mucilage cells. According to her, however, in many cases the contents of the raphide cells have the same viscosity as that of the adjacent cells. With appropriate staining she could not see any difference. This was the case i.a. in several Liliaceae.

FOSTER (1956) remarks that common examples of idioblasts are the so-called "secretory cells' occurring in parenchyma tissue. A more precise denomination is "excretory idioblast", among which he includes all kinds of idioblastic cells differing from the adjacent tissue elements in form and/or kind of the ergastic material they contain when mature. Crystal idioblasts may exactly match normal parenchyma cells in form, but they differ often, especially in raphide idioblasts, in form and size, as illustrated in his paper by a large raphide containing idioblast. Exactly the same picture in EsAU (1965) is called a "mucilage containing raphide cell".

MOLLENHAUER \& LARSON (1966) did ultrastructural research on root tips of Vanilla and Monstera. They found raphide forming cells in both genera to differ from those of adjacent cells. The cytoplasm of cells destined to produce raphide crystals could be differentiated very early in development. An interrelationship in plastids, endoplasmic reticulum, vacuoles, and crystal complexes in the production of raphide crystals is indicated. An internal product accumulates in the later stages of raphide cell development. This product appears to derive from elements of the endoplasmic reticulum, but its composition is unknown. Mucilage is no longer mentioned.

ScoTt \& BYSTROM (1971) showed that mucilage idioblasts have some very typical characteristics not present in the raphide containing cells in the Tetraceroideae.

As for the presence of raphides in all genera of the Tetraceroideae, Dickison 
(1967) stated that he did not see any raphides in Davilla. However, in all the Utrecht samples (3) of Davilla aspera (of which species Dickison saw 3 samples) as well as in Davilla alata and an as yet unidentified specimen, raphides are found in abundance in enlarged and non-enlarged ray cells.

Surveying the evidence of authors from varying disciplines, it seems to be clear that the name "mucilage"cell is better not applied to the raphide containing idioblasts in the ray parenchyma of the Tetraceroideae, as from the latest investigations it seems discutable what the cell content of the raphide containing cells is and whether or not mucilage is present.

\section{ACKNOWLEDGEMENTS}

I wish to express my thanks to Miss Dr. A. M. W. Mennega for her help during this investigation, to Dr. K. U. Kramer for correcting the English text, and to Mr. A. Kuiper for making the photograph.

\section{REFERENCES}

Dickison, W. C. (1967): Comparative morphological studies in Dilleniaceae I. J. Arnold Arboretum 48: $1-30$.

ESAU, K. (1965): Plant anatomy. John Wiley Inc., New York.

Foster, A. S. (1949): Practical plant anatomy. Van Nostrand Co., New York.

- (1956): Plant idioblasts. Protoplasma 46: 184-193.

Hutchinson, J. (1964): The Genera of Flowering Plants, vol. I Clarendon Press, Oxford.

JANsSONIUS, H. H. (1906): Mikrographie des Holzes, Bd. I. Brill, Leiden.

KubrTZKı, K. (1970): Die Gattung Tetracera. Mitt. Bot. Staatss. München 8: 1-98.

- (1971): Doliocarpus, Davilla und verwandte Gattungen. Mitt. Bot. Staatss. München 9: 1-105.

MetCalfe, C. R. \& L. Chalk (1950): Anatomy of the Dicotyledons, vol. I. Clarendon Press, Oxford.

Mollenhauer, H. H. \& D. A. LARSon (1966): Developmental changes in raphide-forming cells. J. Ultrastruct. Res. 16: 55-70.

Pobéguin, Th. (1943): Oxalates de Calcium chez quelques Angiospermes. Ann. Sc. Nat. Bot. ser. 11-4: 1-95.

ScotT, F. M. \& B. G. Bystrom (1970): Mucilaginous idioblasts in Okra. New Research in Plant Anatomy. Academic Press, London. 